\title{
Exploring Student Mobility: University Flows and the Territorial Structure in Viterbo
}

\author{
Ilaria Zambon 1 \\ Department of Agricultural and Forestry Sciences (DAFNE), Tuscia University, Via S. Camillo De Lellis, \\ I-11100 Viterbo, Italy; ilaria.zambon@unitus.it
}

Received: 16 March 2019; Accepted: 22 April 2019; Published: 26 April 2019

\begin{abstract}
Student mobility is a subject of very in-depth study in the urban sciences in the United States while it is little addressed in the literature on Europe, especially for Mediterranean countries such as Italy. The present paper focuses on Viterbo, a city located in the central part of Italy where there is a significant presence of university students. Welcoming more than 10,000 students, the Tuscia University in Viterbo is currently divided into seven Departments, ranging from Agricultural and Forestry sciences to linguistic and juridical studies. For this reason, the Tuscia University is appreciated for its graduate courses rather than the other neighbouring universities, such as Rome. Though the city of Viterbo is not infrastructurally well-connected and forces students to a difficult commute. Based on the limited literature in which student mobility is interrelated with issues affecting the spatial scale, a questionnaire was submitted to a sample of voluntary and anonymous students, which described their experiences giving insight into an intimate relationship between territorial networks and university reality. Results raised many topics of discussion, offering evidence, advantages and perspectives for Tuscia University, its territorial area and even the city of Viterbo.
\end{abstract}

Keywords: student mobility; urban mobility; territorial structure; university; Viterbo

\section{Introduction}

Youth mobility can explain and define spatial flexibility, accessibility and movements of a specific age group, which can profile evolving trans-national networks [1-3]. Current patterns of youth mobility can be classified into two groups: (i) highly educated younger people and (ii) younger individuals with fewer qualifications. However, everyone is inclined to move and change their place of residence in order to increase their education and to find work [4,5]. Geographical youth mobility throughout a region, country and even at the intranational scale is due to several reasons (e.g., of a social nature), nevertheless, its importance can enhance the performance and quality of education and training systems, guaranteeing greater learning and work opportunities for younger people [6,7]. Education is a fundamental factor of occupational class and income [4,5]. Higher qualifications seem necessary for achieving, for example, healthier lives, a higher probability of being employed with greater income and a gratifying job [8-12]. Investing in education often requires greater spatial mobility $[5,13]$ toward more competitive universities with the purpose of achieving highly qualified degrees [11].

Student mobility is a subject of very in-depth study in the urban sciences in the United States [14-16]. However, it is little addressed in the literature in Europe [17-20], especially for Mediterranean countries such as Italy [21-23]. In the last decades, this literature has increased especially dealing with international student mobility [24-30]. Nevertheless, the focus on mobility in the present study is not intended as in other studies, in which it refers to transactional mobility [17,18,31-33], as arising for example from Erasmus projects $[25,34]$. Universities would behave as nodes within a national system of student-graduate mobility $[35,36]$. Nearby study possibilities manage to capture students more easily than far-off ones since "everything is related to everything else but near things are more 
related than distant things" [37]. However, the present work refers to both the commuting (and daily) movements or the choice of moving to live in city where the university is located. The choice to study at a university far from home is found to be connected mainly with reasons of investment (e.g., better future employment opportunities) and/or consumption (e.g., living in a city that guarantees, through its infrastructures, a better "quality of life") [5,11,13].

Student mobility reflects individual decisions reflecting personal characteristics, for example, socio-economic and personal skills [25,38-40]. The outcome of the socio-economic situations of the neighbouring territories,-for example, provinces-is strong, signifying the existence of consumption reasons behind the choice of student mobility [41,42]. Students could choose amongst different universities bearing in mind not only their features but also regarding the quality of the urban area in which the university is located (e.g., greater presence of job opportunities) [43,44]. The propensity for more decentralization is growing in Italy as universities attempt to take their activities nearer to the students' families due to the predominant role of distance [41]. Designed for student mobility, distance is not only about costs but is also about how far students are permitted to live away from their families. This detail is pertinent since Italy is one of the European countries with more robust family bonds $[45,46]$.

The attractiveness of a university is not only associated with the quality of the services offered and its prestige but also the characteristics of the labour market in which the university itself operates and the job opportunities that a degree qualification obtained at the university can ensure [47]. In Italy, the choice to study at a specific university influences where the student will live in the following years [48], often trying to enter in the labour market in the region where s/he obtained the degree [47]. Territorial student mobility is a strategy in which social mobility is at stake [35,48]. In this sense, the territorial movement, the choice of the degree course, personal motivations and individual skills act in close connection in outlining the life paths and the probabilities of individual careers [43,44]. In fact, the study of the regional mobility of graduates in Italy revealed a strong interrelation between the flows of mobility for study and those for work purposes. $[49,50]$.

The present paper focuses on student mobility in Viterbo, a city located in the central part of Italy. In addition to its inhabitants, the mediaeval city of Viterbo is today animated by a significant presence of university students and military people. The first group was investigated in the present study. Viterbo hosts Tuscia University. The name "Tuscia" derives from the current denomination still attributed to the territorial province of Viterbo [51]. Welcoming more than 10,000 students, the Tuscia University is currently divided into seven departments, ranging from agricultural and forestry sciences to linguistic and juridical studies. In 2017, the quality of the research of two departments of the Tuscia University were placed on a list of 120 Italian Departments of Excellence. This is a fact of real relevance, as it will certainly attract many more students to Tuscia University to study in high competence centres [52]. For this reason, Tuscia University is appreciated for its graduate courses over the other neighbouring universities, such as those in Rome. However, the city of Viterbo is not infrastructurally well-connected and therefore forces students to a difficult commute.

Based on a limited literature, student mobility is interrelated with issues affecting spatial scale. A questionnaire was administered to a sample of voluntary and anonymous students, who described their experiences, giving an insight into the intimate relationship between territorial networks and the University's reality. The present paper focuses on two kinds of mobility: territorial mobility and daily mobility. Territorial mobility refers to the mobility of the students, since several students live outside the province of Viterbo or even outside the Lazio region. Their distant places of residence prompt them to go to live in the city where their university is placed. Nevertheless, students can also choose to commute. In this case, the second kind of mobility, that is, daily mobility, is considered since students decide to use specific means of transport for travelling to study. The results raised many topics of discussion, offering evidence, advantages and future perspectives for Tuscia University, its territorial area and the city of Viterbo. 


\section{Materials and Methods}

The Tuscia University, placed in the urban city of Viterbo, has been chosen as the focal point of the analysis. Viterbo is a mediaeval city located in the Lazio region, in the central area of Italy and counts 67 thousand inhabitants. Viterbo is also known since it is in the "Tuscia" area, which historically was inhabited by the Etruscan population. In fact, the province of Viterbo (coinciding with the NUTS3 by Eurostat), which is populated by 318 thousand inhabitants, is also known as the "Tuscia" region.

Based on data offered by the ISTAT census referring to recent decades (from 2002 to 2018), there has been in the city of Viterbo an increase in the old-age index (from 155.7 to 179.8), the replacement index for the active population (from 130.2 to 138.4) and the structure index for the active population (from 98.2 to 138.1). In the province of Viterbo, small industrial and tertiary enterprises represent, in terms of employees, over $90 \%$ of the production system.

In addition to its population, Viterbo is populated by numerous military personnel enlisted in the Aeronautic Military Academy and university students, who study at the Tuscia University. Obviously, the name "Tuscia" derives from the current denomination still attributed to the territorial province of Viterbo [51]. Welcoming more than 10,000 students, the Tuscia University is currently divided into seven departments, ranging from agricultural and forestry sciences to linguistic and juridical studies. In 2017, the quality of the research of two departments of the Tuscia University were placed in a list of 120 Italian Departments of Excellence. This is a fact of real relevance, as it will certainly attract many more students to Tuscia University to study in high competence centres [52]. For this reason, the Tuscia University is appreciated for its graduate courses over other neighbouring universities, such as those in Rome. However, the city of Viterbo is not infrastructurally well-connected and forces students to undertake a difficult commute.

Viterbo has a strong presence of students (about one sixth of the population present in the city compared to total residents which are about 67 thousand). Investigating both the territorial mobility and daily mobility of the students, the presence of a university within a specific territorial area is a generator of strong mobility flows. University students represent a significant segment of "city users" that is certainly useful to quantify and know more about in order to effectively plan services in the territory. Following ISTAT (Italian National Statistical Institute) reports on student mobility, several measures can be used to describe the conformation of the Italian university basins (Table 1), which are:

- the percentage of students coming from over $250 \mathrm{~km}$ away and from outside the region;

- the position indexes (quartiles) of the distances (in kilometres) among the municipality of origin and the municipality of destination of the students;

- number of university members per class of distances between the municipality of origin and the municipality of destination;

- measurements referring to the ellipses of the standard deviations of distances (semi-axis $x$ and $y$ ), which give an indication of the territorial dispersion in terms of distance from the average centre.

Table 1. Mobility measures for the Tuscia University (elaboration from ISTAT report, 2015).

\begin{tabular}{cccccc}
\hline & $\begin{array}{c}\text { Percentage of } \\
\text { Students from } \\
\text { Over } 250 \mathbf{~ k m}\end{array}$ & $\begin{array}{c}\text { Percentage of } \\
\text { Students from } \\
\text { Outside the Region }\end{array}$ & $\begin{array}{c}\text { Third Quartile of } \\
\text { Distances Origin } \\
\text { Destination }\end{array}$ & \multicolumn{2}{c}{$\begin{array}{c}\text { Ellipse Size of Standard } \\
\text { Deviations (in km) }\end{array}$} \\
\cline { 5 - 6 } & 12,6 & 24,6 & 92 & 77 & 31 \\
\hline Tuscia University & 12,6 & 92 Semi-Axis $\boldsymbol{Y}$ \\
\hline
\end{tabular}

Following the recent data (2018) provided by the Ministry of Education on student enrolments, a detailed picture of the academic preferences of students in Viterbo was offered. Subjects concerning the field of engineering are the most appreciated by residents of the province of Viterbo. Data from the Ministry of Education exposed that there is an increase in the number of students who have opted for Tuscia University for their education. The flow of students from the province of Viterbo migrating to 
the universities of the nearby capital city of Rome is very low and is directed mostly to the cities of Northern Italy, while the number of students coming from Southern Italy are numerous.

\subsection{Definition of the Questionnaire}

A questionnaire was chosen for the analysis because it was the easiest way to collect the information and experiences of a sample of students. The multiple-choice (and free answers in some cases) questionnaire was published in the most frequented and active Facebook group of students at Tuscia University. This group has an average of 5 posts per day, in which students interact virtually with each other to learn more about the courses of study, to solve bureaucratic procedures and get information about exams, books and teachers. However, this group is also used for university purposes, for example, disseminating cultural activities, offering shared homes and even sharing means of transport.

With approximately 20 questions (which should take about $5 \mathrm{~min}$ to complete) the anonymous questionnaire was placed online for about two months (see Table 2). Most of the 90 answers were open-ended questions, while some defined very specific classes.

Table 2. Mobility questionnaire.

\begin{tabular}{ll}
\hline & How Old are You? \\
\hline Municipality of residence & \\
\hline You go to Unitus for reasons of: \\
\hline Why did you choose Unitus over other universities? \\
\hline Currently, to attend the university: \\
- I live at my own home \\
- I am commuting between home and university \\
- I share an apartment with other people
\end{tabular}

How long does it take to reach the University (from home or from the place where you live while attending the university)?

- $\quad<10 \mathrm{~min}$

- $\quad 10-30 \mathrm{~min}$

- Between $30 \mathrm{~min}$ and one hour

- $\quad$ One hour-two hours

- More than two hours

Which means of transport do you use to get to the university?

Do you have a season ticket for public transport?

Is the hourly frequency of public transport satisfactory?

Are there any platforms or apps to know in real time the timetables and possible delays/strikes for public transport? If so, what are they? Do you think that a public service portal (e.g., apps with real-time updates, timetables, etc.) would improve mobility in Viterbo?

Do you think that Viterbo should offer a car sharing/bike sharing service?

Why don't you come to university by bike?

If there was a safe and well-connected bike path, would you like to cycle to the university?

In your opinion, if the Tuscia University were better connected to the surrounding area, would there be more students enrolled?

Outside the university, by what means do you move mainly for other activities (recreation, hobbies ... )?

Let's assume you live in Viterbo and they offer you a job in Rome. What do you do?

- You move to Rome

- You Commute (train option)

- You Commute (car option)

- You refuse the job offer

How do you evaluate the infrastructural connection (road and rail network) between Viterbo and Rome? (insufficient, sufficient, good excellent)

How do you evaluate the infrastructural connection (road and rail network) between Viterbo and other regional urban centers? (insufficient, sufficient, good, excellent)

How do you rate the infrastructural connection (roads, railway network) between Viterbo and other cities outside the Lazio region? for example, Florence, Naples, Perugia (insufficient, sufficient, good, excellent) 


\subsection{The Sample}

One hundred and eighty six persons answered the questionnaire (about $8 \%$ of the Facebook group members). The sample is representative of the younger population living in the city of Viterbo (about 3000 people being $20-24$ years old).

The first questions of the survey are focused on defining a specific profile of each participant. Basic questions concern the age and place of residence of each person. Most of them are between 21 and 23 years old (Figure 1). They are probably students engaged in a three-year degree course (Bachelor's degree). In fact, $94 \%$ of the interviewees stated that they attended the Tuscia University for learning reasons, although some of them stated that, after being a student, they have continued their academic career with a $\mathrm{PhD}$ or as a professor within this university. Applicants mainly live in the province of Viterbo. 34 students are from the city, while others are from the neighbouring municipalities, for example, Civitavecchia (7), Montefiascone and Vetralla (5). However, many interviewees live outside Viterbo's province. For instance, 13 individuals are from the capital city of Rome. Moreover, the presence of people coming from other Italian regions, for example, Sicily, Campania and Apulia, can be also noted (Figure 2).
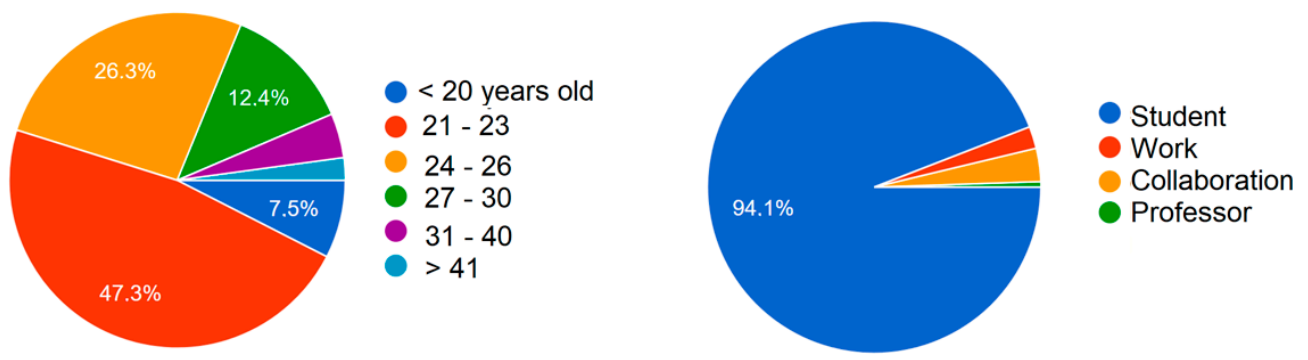

Figure 1. Age groups of questionnaire participants (left) and their current position at the Tuscia University (right).
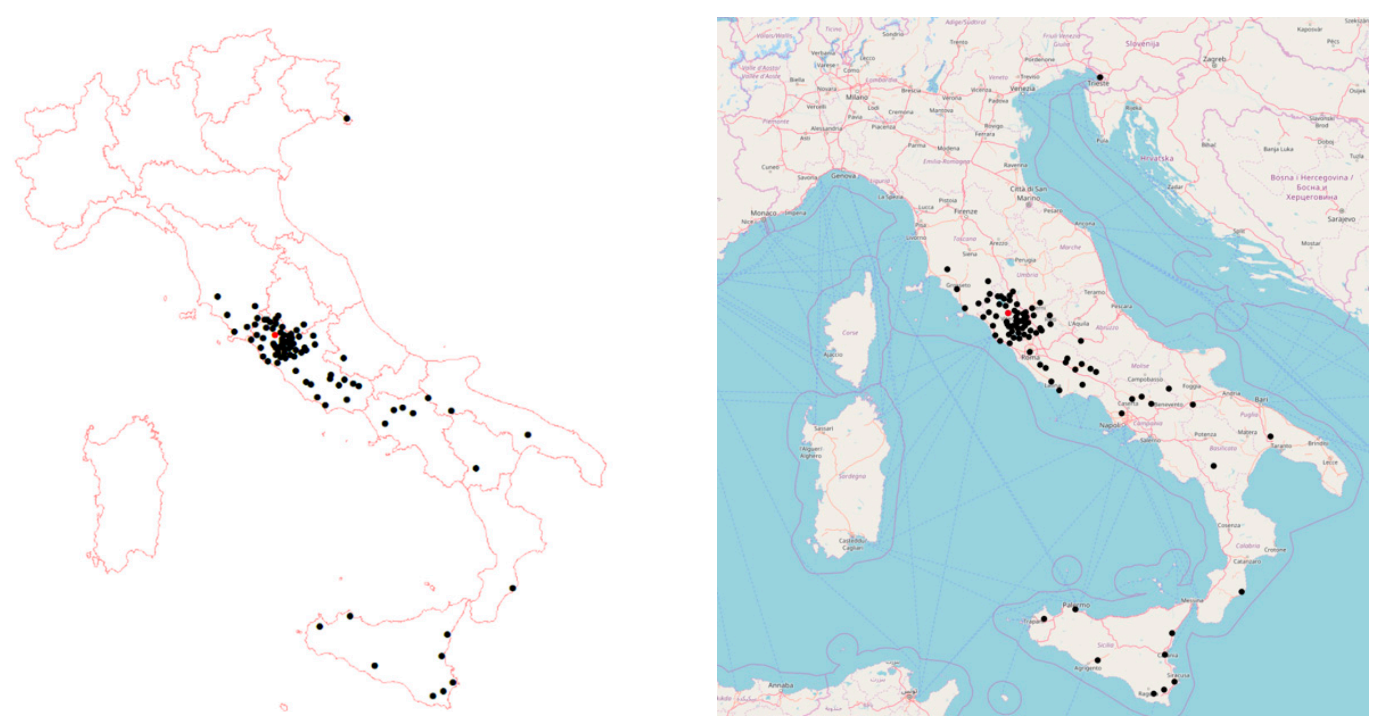

Figure 2. Residents' places of the people interviewed. The red point marks the municipality of Viterbo. Regional boundaries (left) and infrastructure network (right) are reported in light red. 


\section{Results}

Only Italian students answered the questionnaire. In fact, the questionnaire was written in Italian to encourage only students living in Italy to participate. The interest was not to analyse the foreign students who come to Viterbo with the international programs to study (who then temporarily stay in houses or other facilities for some months) but this analysis will focus only on Italian students who want to follow and complete a whole degree course at Tuscia University.

Since many students come from outside the province of Viterbo, the main question was why they chose to enrol in degree courses at Tuscia University (Figure 3). For instance, many universities and degree courses are available in Rome. Firstly, they appreciated the comfortable conditions of its teaching space. In fact, classrooms are well-equipped and allow access to all (including disabled guests), avoiding overcrowding situations. The latter are common in large universities (such as those in Rome). Secondly, the university's proximity to their place of residence was a frequent motivation. Thirdly, the courses on offer at Tuscia University can be considered stimulating and are a consistent motivation to enrol.
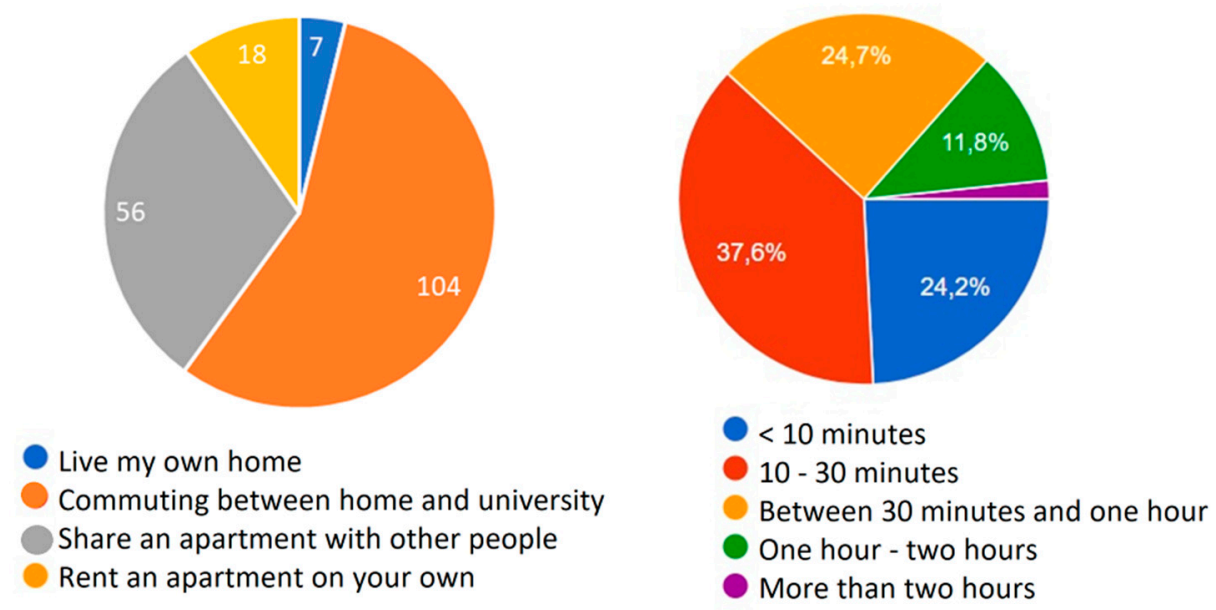

Figure 3. Place of residence during the investigation (left) and time to travel to reach the university from place of residence (right).

Currently, more than half of the applicants commute, travelling from home to university every day. Ten percent decided to share a flat in Viterbo with other people. As for travel times, almost $60 \%$ of them take less than $30 \mathrm{~min}$ to reach the university from their home. Although $37 \%$ of the sample take between half an hour and two hours to get to classes. This highlighted that many students are forced to spend around four hours per day on travel in order to reach the university.

Sixty percent of 21 and 23-year olds opt for a commuter life, while only 35\% choose to share a flat. This figure changes with age since almost half of the students aged 24-26 opt for a commuting life, the rest choose other solutions, for example, a shared flat $(33 \%)$ or a flat on their own $(14 \%)$. Furthermore, most respondents take between 10 minutes and half an hour to get to university from their home. However, this mainly refers to students aged 21 and 23 years old, while this figure falls with increasing age (Figure 4). In fact, those aged between 24 and 26 take only $10 \mathrm{~min}$ to reach university, exposing a tendency to move to live in Viterbo in order to take less time to travel from home to university. 


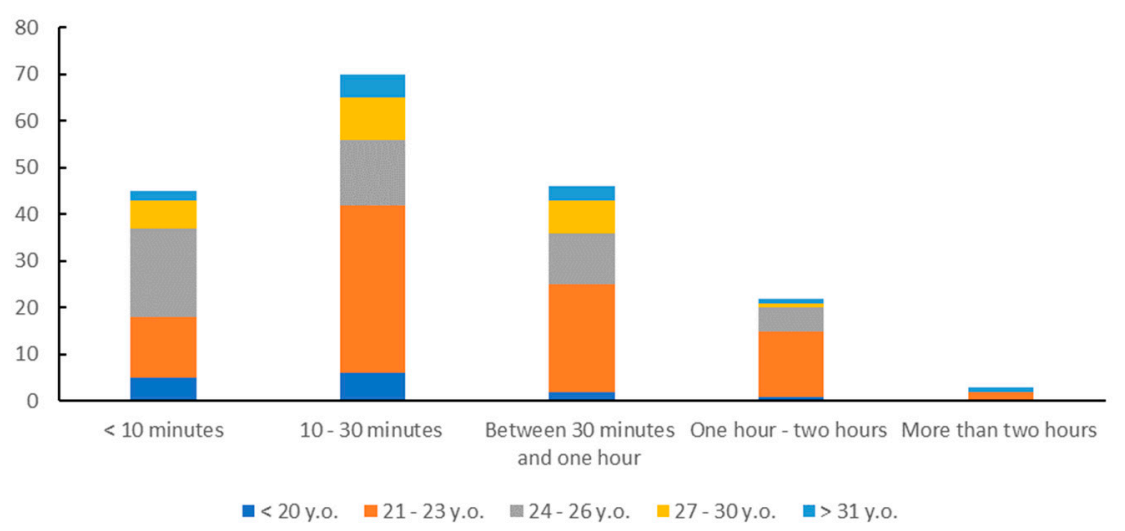

Figure 4. Time for reaching the university from the actual residence place, per each class of age.

Thirty five percent of interviewees said that they go to the university on foot. However, $53 \%$ of them use their car, $36 \%$ public buses and $11 \%$ the train. Concerning sustainable mobility, only 2 persons ride their bike and about 10 individuals choose to share a car with other people.

The questionnaire revealed a high degree of public transport service dissatisfaction. Even if half of the respondents do not need to spend on public transport, about $7 \%$ of them made more than one payment (bus and train) in order to reach the university. About $13 \%$ of interviewees, using public transport, said that they do not have a subscription, preferring daily tickets when it is necessary. In fact, about $65 \%$ of them explained that the frequency of public transport is unsatisfactory. In addition, there are few existing tools (e.g., platforms or apps connected) that let students know about timetables, potential disservice and delays in real time. Only the train firm offers to its customers such a service, while local public transportation does not employ new technologies. For this reason, many respondents $(75 \%)$ argued that it should be indispensable for today's transport companies to inform their customers through appropriate new technologies.

The survey assessed the sustainable degree of respondents, also asking about mobility with low environmental impact (e.g., shared cars, electric cars). The city of Viterbo does not offer any bike or car sharing service. Given such circumstances, it turns out that about $65 \%$ of respondents think it should be compulsory to offer such a service in the urban context. Regarding slow mobility, it was wondered why nobody rides a bicycle. Leaving aside those who live far away (37\%), 21\% of respondents pointed out the high danger of cycling in these territorial areas (Figure 5). In fact, $25 \%$ of them said that the existence of a well-connected and safe bicycle pathway could be a good system for going to university by bike. In fact, in response to the next question "If there is a protected and well-connected bicycle pathway, would you ride a bike?", $50.5 \%$ of respondents answered 'yes,' while $32 \%$ of them said 'no.'

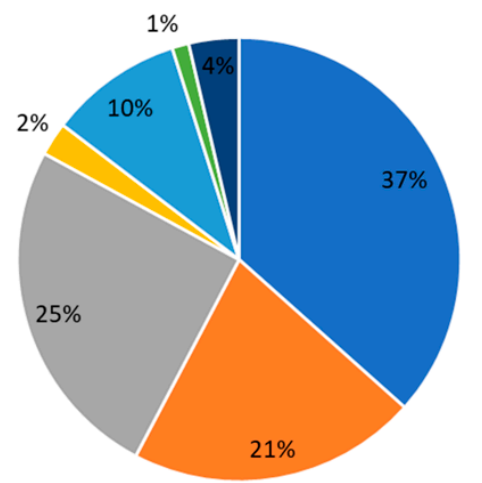

Too far, it takes too long-time.

Too dangerous.

High probability of theft.

Laziness.

I come by bike.

If there was a bike path, I'd be on my bike.

Other.

Figure 5. Answers to the question "Why do not you come to university by bike?".

Based on these premises, Viterbo is probably not well-connected to other places, making both accessibility and mobility difficult. In fact, over $70 \%$ of the respondents believe that Tuscia University 
would probably have more students if the city itself was well-connected. However, many interviewees confirmed that perhaps it is not so correlated as students focus more on the educational program than the transport links.

Excluding university life, most of the interviewees (75\%) said they are also forced to drive their car to reach other places of leisure, while the remaining part depends on public transport. Territorial mobility also has repercussions for professional choices. To the question "Let us hypothesize you live in Viterbo and somebody offers you a job in Rome. What will you do?", almost half of the interviewees would prefer to move to Rome, while the remaining part prefer to become a commuter by public transport $(40 \%)$ or by car $(16 \%)$. Only $3 \%$ of them declared that they would refuse the job offer. This was asked since Rome is the closest city to Viterbo $(80 \mathrm{~km})$ and, as a capital city, can offer numerous job opportunities.

Finally, three more questions allow us to reflect on the degree of transport networks between Viterbo at local, regional and national scales (Figure 6). They are: "how do you evaluate the infrastructural connection (as road and rail network) (i) among Viterbo and Rome, (ii) among Viterbo and other regional urban centres and (iii) among Viterbo and other cities outside Lazio region (e.g., Florence, Naples, Perugia)?". Results showed that insufficient infrastructural connection was the most prevalent answer for all three questions. Strong disappointment was especially recorded for the local scale (66.1\%). The judgments "sufficient" and "good" are of minor frequency, while only one person has expressed that local connections are excellent. In detail, by age group, the transport service with Rome is insufficient for about $70 \%$ of students aged 21 and 23 years. While generally about $60 \%$ of students aged 24 and 26 consider all geographical levels of connection (with Rome, regional and national connections) insufficient.
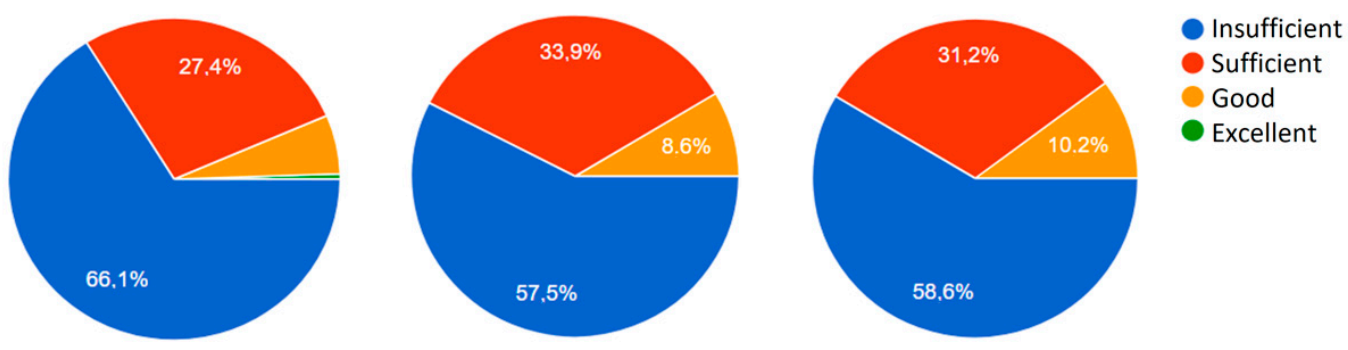

Figure 6. Degree of infrastructural networks between Viterbo at local (left), regional (centre) and national scale (right).

\section{Discussion}

Understanding individual and commuting mobility is a useful tool for knowing the geography of territories but also other implications related to socio-economic conditions, education and territorial structures $[15,37,40,53]$. For example, infrastructures sometimes represent a link but also a limit, especially when they do not permit actual spatial accessibility [54]. Moreover, travel times are fundamental to individual choices, as well as the means of transport used. Just think of the recent phenomena of dispersive urbanization that have stimulated more individual travel than those in public transport [55-59], which is often infrequent and not efficient in small-medium cities in Italy. This strongly influences the presence of certain types of population living in a city. In fact, this study focuses on the territorial and daily mobility of Italian students enrolled at Tuscia University in Viterbo, a medium city located in central Italy.

Over the past decades, international student mobility has become an increasingly important part of the global (and higher) education landscape [27]. However, the present work focuses on another type of student's population that has not been intensively studied but it is of primary interest for universities: namely the mobility of Italian students, who can start and end a possible academic career in a given university in Italy compared to another one. Examining the reasons for selecting a university is central. The issue of territorial mobility faced by a student should not be underestimated, 
as it may affect the final choice. In fact, a student may choose a university that is more accessible and offers a wider range of courses than a smaller and less connected university (even if it is more prestigious). Understanding where students come from is indispensable in order to reflect on the geography of places and the territorial and daily mobility of students, with the intention of highlighting any inadequacies in services and infrastructure.

In this study's questionnaire, only Italian students answered. In fact, the questionnaire was voluntarily written in Italian to select only students living in Italy. The interest was not to analyse the foreign students who come to Viterbo with the international programs (who then temporarily stay in houses or other facilities for some months) [35] but to focus only on the mobility of Italian students who want to follow and complete a whole degree course at Tuscia University. However, the information on the students who arrive in Viterbo with the Erasmus project is lost even though they could offer additional evidence to the work of analysis carried out [31-33,60]. In fact, the students who participated are all Italian, although a percentage of them come from areas outside the region of Latium and other adjacent provinces. Considering the strong presence of students in Viterbo (about one sixth of the population present in the city compared to total residents which are about 67 thousand), the comparison between total population movements and student mobility can provide interesting evidence in favour of either attractiveness factor [59]. Particularly, if a certain region succeeds in attracting many students while not being able to attract more inhabitants, it is easy to imagine that incoming student mobility is more effortlessly attributable to the prestige of the university than to the interesting job opportunities offered by the local labour market [47,61]. Given that two of its seven departments are considered of excellence at national level and it has a didactic proposal that covers different disciplines, most likely the Tuscia university attracts students not only from neighbouring municipalities but also from outside the province. However, infrastructural connections can make it difficult to access Tuscia university and perhaps the choice of this university is discarded in favour of a more accessible and convenient urban city (such as Rome).

The questionnaire highlighted critical issues that coexist, hidden, in the reality of the university in Viterbo. Despite a rich educational program, competent professors, welcoming and not-crowded shared spaces, which are the strengths of this university, there is a strong degree of spatial segregation of Viterbo with other territories. Excluding the 30 Viterbo residents, many young students decided to be a commuter, facing hours and hours of travel to attend classes. Other people chose to share a flat in Viterbo with other people, saving time on travel but certainly not in economic terms since they must pay rent. Particularly, results expressed that as the age of the students increases, they opt for a shared flat or a flat on their own, so as to minimize the time of travelling from home to university.

The study of accessibility and the commuting times of students is relevant, especially for the university $[46,62,63]$ but also for local political decision-makers, who must provide effective mobility plans [64], which allow the start of interesting commuting flows towards the city of Viterbo.

The results raised many topics of discussion, offering future evidence, advantages and perspectives for Tuscia University, its territorial area and even the same city of Viterbo. The lack of an adequate public transport service is mentioned and consequently many interviewees answered that they are constrained to using their own private vehicle to reach the university. The deficiency of alternative transport emerged clearly in the outcomes obtained. It would be useful to introduce some zero-impact mobility tactics, such as: slow mobility, ideally with a safe and well-connected cycle pathway, which would be highly appreciated by students; or sharing transport with other people which would be highly appreciated by students. Nevertheless, the deficiency of public transport service is due to a physical deficit of infrastructural networks. For example, most of the railway line "Rome_Viterbo" has only one track.

A political strategy could therefore be to invest in the quality of the university's offering, as well as in the regional value of the road infrastructure, as it can help to keep and reach young students and qualified graduates in the area. According to recent studies [35,49], the most important migratory decision for the regional accumulation of human capital is to benefit from the choice of university, 
since the great majority of Italian students tend, after graduation, to stay and work where they have completed their education. In Italy, about a quarter of the students were resident in southern Italy and then enrol at a centre-northern university [35]. After the graduation, only one third of them return home, while the remaining two thirds remain in the centre-northern cities. Investing relatively more in university quality and fostering university differentiation can contribute to increasing local job attractiveness.

The (provincial and local) urban planning must try to prove itself to university students, since they are a great portion of the population that lives at least a day in the city of Viterbo. Some objectives of mobility also coincide with those of sustainable development since they can be addressed to:

- a conception of sustainable and inclusive transport modes for employees, students and students and the companies that manage transport, defining suitable home-university journeys;

- construction of cycling modes and means of transport with a lower environmental impact, in collaboration with the municipality, the province and Latium region;

- implementation of measures to promote sustainable and inclusive modes of transport for employees (administrative staff and professors) and students;

- updated mapping of architectural barriers and action on recognized intervention priorities;

- increasing telework and smart working places;

- innovative technological systems (such as apps) for public transport and shared mobility $[65,66]$, which are still missing.

The questionnaire produced interesting results, representing a good portion of the students and precisely defining student mobility. However, there are some limitations. For instance, the questionnaire presents very precise and structured questions in order not to bore respondents and so as not to waste time. It was the only means that allowed adequate collection of data compared to other methods of collection (e.g., brochures with a QR code scattered around the university). For this reason, it would be useful to know about student mobility by defining new methods of analysis that consider the students and not just a limited sample of volunteers. Knowing student mobility and making Tuscia University more accessible and attractive, the university can organize an effective shuttle service for students and make season tickets available to public transport firms. The possibility of establishing mobility management can be a useful alternative to reflect on the sustainable mobility of students, while also ensuring a sustainable development objective [66]. These objectives would be the first strategy to be implemented to make Viterbo a liveable, accessible and smarter city.

\section{Conclusions}

The purpose of obtaining a higher education degree constrains numerous students to (i) move to another city outside their residence's region or (ii) choose to commute during their period at university $[15,35,41,55,62,66]$. The reasons for the territorial and daily mobility of students is due to several reasons $[19,22]$, exposing both strengths and weaknesses. The present work shed light on the territorial and daily mobility of students attending Tuscia University in Viterbo. The sample is based on the experience and opinions of voluntary students who have undertaken a degree course at this university. Although the analysis was based on a questionnaire, the results prompt reflection on the importance of ensuring an appropriate system of mobility especially for commuting students (home to university). The present work aims to emphasize the importance of thinking about student mobility, assuming a vision towards a greater and functional sustainable mobility. However, the main supposition was that a lack of suitable transport network and infrastructure can influence the number of enrolled students [22]. Nevertheless, the results exposed that many students choose Tuscia University for several reasons that (fortunately) prevail over the confirmed lack of accessibility to the same city from other territorial areas. However, many students denounce the lack of effective, frequent and intermodal public transport. In addition, to achieve suitable sustainable development and slow mobility at a local scale, students pointed out the difficulties existing at the urban scale, which can be 
detected also at the regional scale. Today it is relevant for small-medium size universities that offer appreciated educational courses to also offer competitive and convenient means of transport in order to be excellent also in terms of accessibility and sustainable development.

Funding: This research received no external funding.

Acknowledgments: Thank you to all the students of Tuscia University for taking part in the questionnaire anonymously and for reporting their experience.

Conflicts of Interest: The authors declare no conflict of interest.

\section{References}

1. MacDonald, R.; Marsh, J. Disconnected Youth? Growing up in Britain's Poor Neighbourhoods; Palgrave Macmillan: Basingstoke, UK, 2005.

2. Serracant, P. Changing Youth? Continuities and Ruptures in Transitions into Adulthood among Catalan Young People. J. Youth Stud. 2012, 15, 161-176. [CrossRef]

3. Wood, B.E. Youth and Spatiality: Towards Interdisciplinarity in Youth Studies. Young 2017, 25, 209-218.

4. Card, D. The causal effect of education on earnings. In Handbook of Labor Economics; Ashenfelter, O.C., Card, D., Eds.; Elsevier Science: Amsterdam, The Netherlands, 1999; Volume 3, pp. 1801-1863.

5. Schneider, S.L. Nominal comparability is not enough: (In-) equivalence of construct validity of cross-national measures of educational attainment in the European Social Survey. Res. Soc. Stratif. Mobil. 2010, 28, 343-357. [CrossRef]

6. O'Reilly, J.; Eichhorst, W.; Gábos, A.; Hadjivassiliou, K.; Lain, D.; Leschke, J.; Russell, H. Five characteristics of youth unemployment in Europe: Flexibility, education, migration, family legacies and EU policy. Sage Open 2015, 5, 2158244015574962. [CrossRef]

7. Cairns, D.; Smyth, J. I Wouldn't Mind Moving Actually: Exploring Student Mobility in Northern Ireland. Int. Migr. 2011, 49, 135-161. [CrossRef]

8. Baker, D.P.; Leon, J.; Smith Greenaway, E.G.; Collins, J.; Movit, M. The education effect on population health: A reassessment. Popul. Dev. Rev. 2011, 37, 307-332. [CrossRef]

9. Hadjar, A.; Samuel, R. Does upward socila mobility increase life satisfaction? A longitudinal analysis using British and Swiss panel data. Res. Soc. Stratif. Mobil. 2015, 39, 48-58.

10. Powdthavee, N.; Lekfuangfu, W.N.; Wooden, M. What's the good of education on our overall quality of life? A simultaneous equation model of education and life satisfaction for Australia. J. Behav. Exp. Econ. 2015, 54, 10-21. [CrossRef] [PubMed]

11. Schuck, B.; Steiber, N. Does intergenerational educational mobility shape the well-being of young europeans? Evidence from the European Social Survey. Soc. Indic. Res. 2018, 139, 1237-1255. [CrossRef]

12. Reynolds, J.R.; Ross, C.E. Social stratification and health: Education's benefit beyond economic status and social origin. Soc. Probl. 1998, 45, 221-247. [CrossRef]

13. Torche, F. Analyses of intergenerational mobility: An interdisciplinary review. Ann. Am. Acad. Political Soc. Sci. 2015, 657, 37-62. [CrossRef]

14. Prazeres, L.; Findlay, A.; McCollum, D.; Sander, N.; Musil, E.; Krisjane, Z.; Apsite-Berina, E. Distinctive and comparative places: Alternative narratives of distinction within international student mobility. Geoforum 2017, 80, 114-122. [CrossRef]

15. Voight, A.; Giraldo-García, R.; Shinn, M. The effects of residential mobility on the education outcomes of urban middle school students and the moderating potential of civic engagement. Urban Educ. 2017, 0042085917721956. [CrossRef]

16. Welsh, R.O. School hopscotch: A comprehensive review of K-12 student mobility in the United States. Rev. Educ. Res. 2017, 87, 475-511. [CrossRef]

17. Caruso, R.; De Wit, H. Determinants of mobility of students in Europe: Empirical evidence for the period 1998-2009. J. Stud. Int. Educ. 2015, 19, 265-282. [CrossRef]

18. Chessa, S. Formazione Universitaria e Mobilità Studentesca in Europa; Una Lettura Sociologica; FrancoAngeli: Milano, Italy, 2009; pp. 1-176.

19. Sin, C.; Tavares, O.; Neave, G. Student mobility in Portugal: Grappling with adversity. J. Stud. Int. Educ. 2017, 21, 120-135. [CrossRef] 
20. Toscano, M.; Cannas da Silva, L.; Heitor, T. The Centrality of (Vocational-Oriented) Knowledge Assessing Location and Configuration of Polytechnic Institutes in Portugal. Urban Sci. 2018, 2, 75. [CrossRef]

21. Dal Bianco, A.; Spairani, A.; Ricciari, V. La mobilità degli studenti in Italia: un'analisi empirica. Riv. Econ. Stat. Territ. 2010. [CrossRef]

22. Demarinis, G.; Iaquinta, M.; Leogrande, D.; Viola, D. Analisi quantitativa della mobilità studentesca negli atenei italiani. In Confronto Territoriale fra Domanda e Offerta di Formazione Universitaria; Università degli studi di. Bari Aldo Moro: Bari, Italy, 2011.

23. Grossi, L.; Serra, S. Mobilità Studentesca e Successo Formative; Armando Editore: Roma, Italy, 2002.

24. Byram, M.; Dervin, M. Students, Staff and Academic Mobility in Higher Education; Cambridge Scholars Publishers: Newcastle, UK, 2008.

25. Findlay, A.M.; King, R.; Smith, F.M.; Geddes, A.; Skeldon, R. World class? An investigation of globalisation, difference and international student mobility. Trans. Inst. Br. Geogr. 2012, 37, 118-131. [CrossRef]

26. Guruz, K. Higher Education and International Student Mobility in the Global Knowledge Economy; State University of New York Press: Albany, NY, USA, 2008.

27. King, R.; Lulle, A. Rhythmic island: Latvian migrants in Guernsey and their enfolded patterns of space-Time mobility. Popul. Space Place 2015, 21, 599-611. [CrossRef]

28. Solimano, A. The International Mobility of Talent; Oxford UP: Oxford, UK, 2008.

29. Varghese, N. Globalization of Higher Education and Cross-Border Student Mobility; International Institute for Education Planning: Paris, France, 2008.

30. Waters, J.; Brooks, R. 'Vive la diffe rence?' The international experiences of UK students overseas. Popul. Space Place 2011. [CrossRef]

31. Lindberg, M.E. Student and early career mobility patterns among highly educated people in Germany, Finland, Italy and the United Kingdom. High. Educ. 2009, 58, 339-358. [CrossRef]

32. Mancini, T.; Carbone, E. Identità territoriale, nazionale, europea, culturale e cosmopolita e pregiudizio latente e manifesto. Una ricerca su un gruppo di studenti universitari. G. Ital. Psicol. 2007, 34, 117-146.

33. Verbik, L.; Lasanowski, V. International student mobility: Patterns and trends. World Educ. News Rev. 2007, 20,1-16.

34. Findlay, A. An assessment of supply and demand-side theorizations of international student mobility. Int. Migr. 2011. [CrossRef]

35. Ciriaci, D. Does university quality influence the interregional mobility of students and graduates? The case of Italy. Reg. Stud. 2014, 48, 1592-1608. [CrossRef]

36. Faggian, A.; Mccann, P. Human capital flows and regional knowledge assets: a simultaneous equation approach. Oxford Econ. 2006, 58, 475-500. [CrossRef]

37. Tobler, W.R. A computer movie simulating urban growth in the Detroit region. Econ. Geogr. 1970, 46, $234-240$. [CrossRef]

38. Dreher, A.; Poutvaara, P. Student Flows and Migration: An Empirical Analysis; CESifo Working Paper; Center for Economic Studies and Ifo Institute (CESifo): Konstanz, Germany, 2005; Volume 190.

39. King, R. Towards a new map of European migration. Int. J. Popul. Geogr. 2002, 8, 89-106. [CrossRef]

40. King, R. Geography, islands and migration in an era of global mobility. Isl. Stud. J. 2009, 4, 53-84.

41. Determinants of College Student Migration in Italy: Empirical Evidence from a Gravity Approach. Available online: https://ssrn.com/abstract=1063481 (accessed on 22 April 2019).

42. Bruno, G.; Improta, G. Using gravity model for the evaluation of new university site locations: A case study. Comput. Oper. Res. 2008, 35, 436-444. [CrossRef]

43. Davanzo, J. Repeat migration in the United states: Who moves back and who moves on? Rev. Econ. Stat. 1983, 65, 85-101. [CrossRef]

44. McHugh, R.; Morgan, J. The Determinants of Interstate Student Migration: A Place-to-Place Analysis. Econ. Educ. Rev. 1984, 3, 269-278. [CrossRef]

45. Alesina, A.; Giuliano, P. The power of the family. J. Econ. Growth 2010, 15, 93-125. [CrossRef]

46. Türk, U. Socio-Economic Determinants of Student Mobility and Inequality of Access to Higher Education in Italy. Netw. Spat. Econ. 2019, 8, 1-24. [CrossRef]

47. Dotti, F.; Fratesi, U.; Lenzi, C.; Percoco, M. Local labour markets and the interregional mobility of italian university students. Spat. Econ. Anal. 2013, 8, 443-468. [CrossRef] 
48. Panichella, N. Migration strategies and occupational outcomes of southern Italian graduates. J. Mod. Ital. Stud. 2013, 18, 72-89. [CrossRef]

49. Bacci, S.; Chiandotto, B.; Di Francia, A.; Ghiselli, S. Graduates job mobility: A longitudinal analysis. Statistica 2008, 3-4, 255-279.

50. Tosi, F.; Impicciatore, R.; Rettaroli, R. Individual skills and student mobility in Italy: A regional perspective. Reg. Stud. 2018, 1-13. [CrossRef]

51. Zambon, I.; Colantoni, A.; Monarca, D.; Cecchini, M.; Salvati, L. Characterizing population dynamics and early processes of urbanization in rural Tuscia, central Italy. Rom. J. Reg. Sci. 2017, 11, 76-101.

52. Cattaneo, M.; Malighetti, P.; Meoli, M.; Paleari, S. University spatial competition for students: The Italian case. Reg. Stud. 2017, 51, 750-764. [CrossRef]

53. Miralles-Guasch, C.; Melo, M.M.; Marquet, O. A gender analysis of everyday mobility in urban and rural territories: From challenges to sustainability. Gend. Place Cult. 2016, 23, 398-417. [CrossRef]

54. Ford, A.; Barr, S.; Dawson, R.; James, P. Transport accessibility analysis using GIS: Assessing sustainable transport in London. ISPRS Int. J. Geo Inf. 2015, 4, 124-149. [CrossRef]

55. Ciommi, M.; Chelli, F.M.; Salvati, L. Integrating parametric and non-parametric multivariate analysis of urban growth and commuting patterns in a European metropolitan area. Qual. Quant. 2019, 53, 957-979. [CrossRef]

56. Salvia, R.; Serra, P.; Zambon, I.; Cecchini, M.; Salvati, L. In-Between Sprawl and Neo-Rurality: Sparse Settlements and the Evolution of Socio-Demographic Local Context in a Mediterranean Region. Sustainability 2018, 10, 3670. [CrossRef]

57. Perini, L.; Colantoni, A.; Renzi, G.; Salvati, L. Urban sprawl, soil sealing and impacts on local climate. In Urban Expansion, Land Cover and Soil Ecosystem Services; Taylor \& Francis Routledge Studies in Urban Ecology: Italy, 2017; Volume 193, ISBN 9781317504719.

58. Colantoni, A.; Grigoriadis, E.; Sateriano, A.; Venanzoni, G.; Salvati, L. Cities as selective land predators? A lesson on urban growth, deregulated planning and sprawl containment. Sci. Total Environ. 2016, 545, 329-339. [CrossRef]

59. Salvati, L.; Zambon, I. Does Residential Mobility Anticipate Urban Growth? The Importance of the Local Socioeconomic Context in a European Metropolitan Region. Popul. Rev. 2018, 57, 57. [CrossRef]

60. Campobasso, F.; Fanizzi, A. Attività e Servizi Universitari nel Giudizio dei Laureati Dell'ateneo Barese; Professionalità nei Servizi Innovativi per Studenti Universitari: Padova, Italy, 2008; Volume 173.

61. Cattaneo, M.; Malighetti, P.; Paleari, S.; Redondi, R. The role of the air transport service in interregional long-distance students' mobility in Italy. Transp. Res. Part A: Policy Pract. 2016, 93, 66-82. [CrossRef]

62. Kobus, M.B.; Van Ommeren, J.N.; Rietveld, P. Student commute time, university presence and academic achievement. Reg. Sci. Urban Econ. 2015, 52, 129-140. [CrossRef]

63. Hynes, M. At a crossroads: Investigating automobility and its implications for local urban transport policy design. Urban Sci. 2017, 1, 14. [CrossRef]

64. Shaheen, S.; Chan, N. Mobility and the sharing economy: Potential to facilitate the first-and last-mile public transit connections. Built Environ. 2016, 42, 573-588. [CrossRef]

65. Gössling, S. ICT and transport behavior: A conceptual review. Int. J. Sustain. Transp. 2018, 12, 153-164. [CrossRef]

66. Marique, A.F.; Dujardin, S.; Teller, J.; Reiter, S. School commuting: The relationship between energy consumption and urban form. J. Transp. Geogr. 2013, 26, 1-11. [CrossRef]

(C) 2019 by the author. Licensee MDPI, Basel, Switzerland. This article is an open access article distributed under the terms and conditions of the Creative Commons Attribution (CC BY) license (http://creativecommons.org/licenses/by/4.0/). 